Sains Malaysiana 49(5)(2020): 1067-1080

http://dx.doi.org/10.17576/jsm-2020-4905-11

\title{
The Cartilaginous Tissue Formation using Sry (Sex Determining Region Y)-BOX9 and Telomerase Reverse Transcriptase Genes Transfected Chondrocytes: In vivo Approach \\ (Pembentukan Tisu Tulang Rawan menggunakan Sry (Penentu Jantina Rantau Y)-BOX9 dan Telomerase Gen Transkripsi Berbalik Kondrosit Transfeksi: Pendekatan in vivo)
}

\author{
NOORHIDAYAH MD NAZIR, AHMAD HAFIZ ZUlKIFly, KAMARUl ARIFFIN KHALID, IsMAIL ZAINOL, \\ ZAITUNNATAKHIN ZAMLI \& MUNIRAH SHA'BAN*
}

\begin{abstract}
The shortage of organ supply reduces the success rate of organ transplantation. Hence, tissue regeneration has been initiated with the intention of improving the available treatment modalities. Articular cartilage is a suitable tissue for this purpose due to its limited self-heal ability. This study aims to evaluate the cartilaginous properties of in vivo constructs formed using chondrocytes transfected with the combination of sry (sex determining region y)-box9 (SOX9) and telomerase reverse transcriptase (TERT) genes (SOX9/TERT-transfected chondrocytes) seeded on a three-dimensional (3D) poly(lactic-co-glycolic) acid (PLGA)-based scaffold. The rabbit's articular chondrocytes $(n=6)$ were transfected with SOX9 and TERT genes via lipofection. The non-transfected chondrocyte (NTC) was used as a control. A total of $1 \times 10^{5}$ cells were seeded on a PLGA and PLGA/fibrin hybrid scaffolds to form constructs. The resulted constructs were SOX9/TERT-PLGA/fibrin, NTC-PLGA/fibrin, SOX9/TERT-PLGA and, NTC-PLGA. All constructs were cultured for three weeks prior to subcutaneous implantation into the athymic mice for two and four weeks. The constructs'structural and functional aspects were evaluated using macroscopic observation, compression-stress analysis, histology, quantitative sulphated glycosaminoglycan (sGAG) assay and cartilage-specific genes (ACAN, COL2A1, SOX9), TERT, and MMP13 expression analysis. The constructs demonstrated a cartilage-like appearance. The constructs' rigidity corresponded to the homogenous cells and extracellular matrix distribution in the week-4 constructs. Correspondingly, the cartilaginous matrix components were visualised at the pericellular matrix region of the construct, supported by the increment of quantitative sGA content. The SOX9/TERT-PLGA/fibrin exhibited better genes expression and cartilaginous phenotypes than the other construct groups. The SOX9/TERT-PLGA/fibrin construct facilitated cartilaginous tissue formation.
\end{abstract}

Keywords: Cartilage; chondrocytes; in vivo; SOX9; TERT; transfection

ABSTRAK

Kekurangan bekalan organ menurunkan kadar kejayaan pemindahan organ. Oleh itu, penjanaan semula tisu telah diusahakan bagi memperbaiki modaliti rawatan sedia ada. Rawan artikul ialah tisu yang sesuai untuk kegunaan ini oleh sebab kebolehan swapulihnya yang terbatas. Kajian ini bertujuan untuk menilai ciri-ciri tulang rawan binaan in vivo yang dibentuk melalui transfeksi gabungan gen sry (penentu jantina rantau y)-box9 (SOX9) dan gen telomerase transkriptase membalik (TERT) ke dalam sel kondrosit yang disemai atas kerangka tiga dimensi (3D) berasaskan asid poli(laktik-ko-glikolik) (PLGA). Sel kondrosit artikul arnab $(n=6)$ telah ditransfeksi dengan gen SOX9 dan TERT melalui kaedah lipofeksi. Sel kondrosit tanpa transfeksi (NTC) telah digunakan sebagai kawalan. Sejumlah $1 \times 10^{5}$ sel telah disemai atas kerangka PLGA 3D dan kerangka hibrid PLGA/fibrin untuk membentuk binaan. Binaan yang terhasil ialah SOX9/TERT-PLGA/fibrin, NTC-PLGA/fibrin, SOX9/TERT-PLGA dan NTC-PLGA. Semua binaan telah dikultur selama tiga minggu sebelum diimplantasi secara subkutaneus ke dalam tikus tanpa timus selama dua dan empat minggu. Aspek struktur dan fungsian binaan telah dinilai menggunakan pemerhatian makroskopik, analisis tegasan mampatan, histologi, asai kuantitatif glikosaminoglikan sulfat ( $S G A G)$ dan analisis ekspresi gen khusus tulang rawan (ACAN, COL2A1, SOX9), TERT dan MMP13. Binaan menunjukkan rupa tulang rawan. Ketegaran binaan sejajar dengan taburan sel homogen dan matriks ekstrasel pada binaan minggu ke-4. Komponen matriks tulang rawan telah dilihat pada binaan di bahagian matriks periselular, disokong oleh kenaikan kandungan kuantitatif sGAG. SOX9/TERT-PLGA/ fibrin mempamerkan ekpresi gen dan fenotip tulang rawan yang lebih baik berbanding kumpulan binaan yang lain. Binaan SOX9/TERT-PLGA/fibrin memudahkan pembentukan tisu tulang rawan.

Kata kunci: In vivo; sel kondrosit; SOX9; TERT; transfeksi; tulang rawan 


\section{INTRODUCTION}

The establishment of cell culture helps the researchers to study the cells' behaviour. A recognised cartilage repair treatment modality, autologous chondrocyte implantation (ACI) applies cell culture technique using the retrieved chondrocytes from the damaged cartilage site (Ogura et al. 2019). The cultured chondrocytes are implanted to the site with the hope that new tissue will grow at the defected area. However, the fate of the implanted cell is unknown because it has been indicated that the cultured chondrocytes tend to dedifferentiate in monolayer culture (Kavand et al. 2019; Mohd Yunus et al. 2019; Vermeulen et al. 2019).

The introduction of tissue engineering and regenerative medicine (TERM) gives hope to improve the existing medical intervention, particularly for treating cartilage damage. In TERM, tissue regeneration is achieved by incorporating the cells into the $3 \mathrm{D}$ scaffold with the supplementation of signalling cues. Hence, the $3 \mathrm{D}$ culture setting is expected to provide a better implant quality than the monolayer culture because the cultured cells are developing towards functioning tissue (Prosser et al. 2019). It shows the importance of cells interaction in the scaffold as the formed construct mimics the tissue in its actual condition, that is in the form of multicellular layers. Several cartilage TERM studies have demonstrated cartilaginous phenotype restoration in the in vitro cultured construct (Kudva et al. 2018; Liu et al. 2019; Elakkiya et al. 2019). Hence, the confirmation of tissue development in the in vitro construct has to be analysed in the in vivo setting, as it is close to an actual environment. For instance, it has been reported that the implanted construct in an ectopic animal model (athymic mice) has exhibited positive tissue growth in just four weeks (Deng et al. 2019; Joydip et al. 2013), six weeks (Zhang et al. 2019), seven weeks (Zhu et al. 2014)chondrocytes can maintain stable chondrogenic phenotype in ectopic microenvironment, which was speculated to be related with the existence of anti-angiogenic factors such as Chondromodulin-I (Chm-I and eight weeks (Sabatino et al. 2012) post-implantation.

In this study, the construct is formed by seeding the chondrocytes transfected with SOXO and TERT genes (SOX9/TERT-transfected chondrocytes) in PLGA/fibrin and PLGA scaffolds. $S O X 9$ is the chondrogenesis master regulator which activates other cartilaginous markers, namely collagen type-II and aggrecan and suppresses hypertrophy marker, collagen type-X in non-hypertrophic chondrocytes (Zhang et al. 2017). In the case of TERT, it is anticipated to delay the apoptosis or senescence of the cells. The potential of SOX9/TERT-transfected chondrocytes has been verified in the ex vivo experimental setting (Noorhidayah et al. 2019). The finding has demonstrated the formation of cartilaginous tissue with a stable phenotypic expression in the construct that has been formed using SOX9/TERT-transfected chondrocytes compared to the other cell groups. However, the tissue's histoarchitecture has not fully occupied or infiltrated into the porous scaffold. As a continuation of the report, this study aims to evaluate the constructs' performance in the in vivo environment.

\section{MATERIALS AND METHODS}

CHONDROCYTES ISOLATION

With the approval of the Institutional Animal Care and Use Committee, International Islamic University Malaysia (IACUC-IIUM) (IIUM/IACUC/Approval 2015/ [5]/[24]), the 6-months old New Zealand White rabbits $(n=6)$ were obtained from a commercially available source in Kuantan, Pahang. Articular cartilage was aseptically harvested from the femoral condyle and tibial plateau. The chondrocytes isolation procedure was conducted as described in Noorhidayah et al. (2019). The cultured cells were supplemented with 1:1 of Ham's F12 nutrient mixture (F12) and Dulbecco's Modified Eagles Medium (DMEM) culture medium supplemented with 1\% (v/v) AA (Gibco, Grand Island, NY), 10\% (v/v) Fetal Bovine Serum (FBS) (Gibco, Grand Island, NY), 1\% (v/v) GlutaMAX ${ }^{\mathrm{TM}}$ (Gibco, Grand Island, NY), 1\% (v/v) 4-(2-hydroxyethyl)-1-piperazineethanesufonic acid (HEPES) buffer (Gibco, Grand Island, NY) and 1\% (v/v) $50 \mu \mathrm{g} / \mathrm{mL}$ of ascorbic acid (Sigma-Aldrich, St. Louis, Missouri, USA). The cultures were maintained in a $5 \%$ $\mathrm{CO}_{2}$ incubator (Thermo Scientific, Barnstead Lab Line, USA) at $37{ }^{\circ} \mathrm{C}$. The cells were sub-cultured to passage- 1 (P1) once it reached 70\%-90\% confluency.

\section{SOX9 AND TERT GENES TRANSFECTION}

The P1 cells were transfected with pcDNA3-SOX9 and/or pBABE-neo-hTERT plasmids via lipofection (Lipofectamine $^{\mathrm{TM}}$ 3000, Invitrogen, CA, USA) by following the manufacturer's protocol (Noorhidayah et al. 2019). The procedure managed to achieve the transfection efficiency of $60.38 \%$ (unpublished data). The cells were grouped into (a) non-transfected chondrocytes (NTC, control) and (b) SOX9/TERT-transfected chondrocytes. The cells were detached from the culture plate with Trypsin-ethylenediaminetetraacetic acid (EDTA) (Gibco, Grand Island, NY, USA) after $24 \mathrm{~h}$ and were seeded in the scaffold.

\section{FORMATION OF 3D CONSTRUCT}

The disc-shaped ( $3 \mathrm{~mm}$ height $\times 7 \mathrm{~mm}$ diameter) $20 \%$ (w/v) PLGA (mole ratio: 65:35, Resomer RG653H, Sigma-Aldrich, St. Louis, Missouri, USA) scaffold with the pore size of $180 \mu \mathrm{m}-250 \mu \mathrm{m}, 85.2 \%$ porosity was fabricated using solvent casting and salt leaching technique (Munirah et al. 2008a; Noorhidayah et al. 2019). The SOX9/TERT-transfected chondrocytes and NTC at P1 were seeded into a sterilised PLGA scaffold with and without rabbit's plasma-derived fibrin with the concentration of $865,800 \mathrm{cell} / \mathrm{cm}^{3}(100,000$ cells per 7 
$\mathrm{mm} \times 3 \mathrm{~mm}$ scaffold) (Table 1 ). The cells seeded in the PLGA with $250 \mu \mathrm{L}$ fibrin was coagulated by adding 50 $\mu \mathrm{L}$ calcium chloride $\left(\mathrm{CaCl}_{2}\right)$ (Sigma-Aldrich, St. Louis,
Missouri, USA). The formed constructs were cultured for three weeks in vitro.

TABLE 1. The experimental groups and relevant abbreviations

\begin{tabular}{|c|c|c|c|}
\hline Scaffolds & & Cells Source & Abbreviation Used \\
\hline \multirow[t]{2}{*}{ PLGA and fibrin } & & SOX 9 and $T E R T$-transfected chondrocytes & $\begin{array}{c}\text { SOX9/TERT-PLGA/fibrin } \\
(\mathrm{S} / \mathrm{T}-\mathrm{P} / \mathrm{F})\end{array}$ \\
\hline & & Non-transfected chondrocytes & $\begin{array}{l}\text { NTC-PLGA/fibrin } \\
\text { (C-P/F) }\end{array}$ \\
\hline \multirow[t]{2}{*}{$\begin{array}{c}\text { PLGA } \\
\text { *without fibrin }\end{array}$} & $\begin{array}{l}\text { seeded } \\
\text { with }\end{array}$ & $S O X 9$ and $T E R T$-transfected chondrocytes & $\begin{array}{c}\text { SOX9/TERT-PLGA } \\
\text { (S/T-P) }\end{array}$ \\
\hline & & Non-transfected chondrocytes & $\begin{array}{l}\text { NTC-PLGA } \\
\text { (C-P) }\end{array}$ \\
\hline
\end{tabular}

\section{CONSTRUCT IMPLANTATION}

The in vitro cultured constructs were implanted subcutaneously at the dorsum of 6-week old athymic mice $(n=6)$. General anaesthesia was carried out with an intramuscular injection of zoletil $(25 \mathrm{mg} / \mathrm{kg}$ ) (Virbac Laboratories, Carros, France) and xylazine (12 mg/ $\mathrm{kg}$ ) (Ilium, Troy Laboratories Pty Limited, Australia) (ZX) cocktail (Choi \& Jeong 2017). Under the aseptic condition, four subcutaneous pockets were created per mouse by making a small horizontal incision (approximate of $1 \mathrm{~cm}$ ) on the dorsum of the mouse's skin. The four pockets were created by manoeuvring a blunt surgical scissor, enough to fit a $7 \mathrm{~mm} \times 3 \mathrm{~mm}$ scaffold in the pocket. The construct was carefully inserted in each pocket and sutured with resorbable stitches, 3.0 Vicryl (Johnson \& Johnson Healthcare System. Inc., Hoes Lane, Piscataway, New Jersey, USA). The mice were allowed to move freely in an individually ventilated cage (IVC). The in vivo constructs were harvested at week-2 and week- 4 by overdosing the mice with the ZX cocktail.

\section{MACROSCOPIC OBSERVATION}

The constructs were observed at room temperature for its gross appearance, shape, and colour. Simple palpation using forceps was conducted to confirm the construct's rigidity (Alsberg et al. 2002).

\section{COMPRESSION-STRESS ANALYSIS}

The analysis was conducted using a biomechanicaltesting machine (Instron E300, Oswald Elektromotoren
$\mathrm{GmbH}$, Germany). The construct was stored in normal saline before testing. A constant compressive strain rate of $1 \mathrm{~mm} / \mathrm{min}$ was applied until failure, and a stress-strain curve was generated. The generated data was used to plot the result.

\section{HISTOLOGICAL STAINING}

The construct was fixed in 10\% Neutral Buffered Formalin (NBF) (Surgipath ${ }^{\circledR}$, Leica Microsystem, USA), processed and sectioned to $5 \mu \mathrm{m}$. Haematoxylin and eosin (H\&E) (Haematoxylin 560 $\mathrm{MX}^{\circledR}$, Leica Biosystem Richmond Inc, Canada), alcian blue, pH 2.5 (Merck KGaA, Darmstadt, Germany), toluidine blue, $\mathrm{pH} 1.0$ (Sigma-Aldrich, St. Louis, Missouri, USA) and 0.1\% safranin O (Merck KGaA, Darmstadt, Germany) were conducted to observe the structural and functional aspects of the construct.

\section{QUANTITATIVE SGAG ASSAY}

The construct was digested in $125 \mu \mathrm{g} / \mathrm{mL}$ papain enzyme (Sigma-Aldrich, St. Louis, Missouri, USA) for $16 \mathrm{~h}$ at $60{ }^{\circ} \mathrm{C}$. The sGAG detection was conducted using Alcian Blue assay by following the procedure in Karlsson and Björnsson (2001), as described in Noorhidayah et al. (2019). The absorbance was measured using a VersaMax microplate reader (Molecular Devices, San Jose, California, USA) at $620 \mathrm{~nm}$. The data were normalised with the construct's dry weight. 


\section{CARTILAGINOUS MARKERS EXPRESSION ANALYSIS}

SOX9, aggrecan $(A C A N)$ and collagen type-II (COL2A1), collagen type-I (COL1A2), TERT and MMP13 genes expression were evaluated using real-time polymerase chain reaction (RT-PCR). The primers are listed in Table
2. The reaction was conducted using CFX96 Touch $^{\mathrm{TM}}$ Real-Time PCR Detection System (BIO RAD, Hercules, California, USA). The PCR profile for the respective markers are as follows: initial denaturation, $95^{\circ} \mathrm{C}$ for 5 min, 39 cycles of $95^{\circ} \mathrm{C}$ for $5 \mathrm{~s}$ and $60.3{ }^{\circ} \mathrm{C}$ for $30 \mathrm{~s}$.

TABLE 2. The used molecular markers primer sequences

\begin{tabular}{|c|c|c|c|}
\hline Primer's name & Sequences & Accession number & $\begin{array}{l}\text { PCR } \\
\text { product } \\
\text { (bp) }\end{array}$ \\
\hline \multirow[t]{2}{*}{ HPRT1 } & F:5'-GCA GAC CTT GCT TTC CTT GGT-3' & NM_001105671.1 & 62 \\
\hline & R:5'-GCA GGC TTG CGA CCT TGA C-3' & & \\
\hline \multirow[t]{2}{*}{ COL1A2 } & F:5'-GGT GGT TAC GAC TTT GGT TA-3' & NM_001195668.1 & 95 \\
\hline & R:5'-GCA TCG ACT TCA TAG TCC TT-3' & & \\
\hline \multirow[t]{2}{*}{ COL2A1 } & F:5'-TGC AGG AGG GGA AGA GGT AT-3' & NM_001195671.1 & 123 \\
\hline & R:5'-GGC AGT CCT TGG TGT CTT CA-3' & & \\
\hline \multirow[t]{2}{*}{$A C A N$} & F:5'-ACA CTG GCG AGT ACT GTG AC-3' & XM_008251722.2 & 95 \\
\hline & R:5'-TGT GAA AGA GTC GCT GGC AT-3' & & \\
\hline \multirow[t]{2}{*}{ SOX9 } & F:5'-AAG ATG ACC GAC GAG CAG GA-3' & XM_008271763.2 & 116 \\
\hline & R:5'-CGT GTA TTC TCG GTG TCG GA-3' & & \\
\hline \multirow[t]{2}{*}{ TERT } & F:5'-TTG CGG AAG ACA GTG GTG AA-3' & NM_198253.2 & 176 \\
\hline & R:5'-AGA CTG GCT CTG ATG GAG GT-3' & & \\
\hline
\end{tabular}

\section{STATISTICAL ANALYSIS}

From the compression-stress analysis, sGAG assay and cartilaginous markers expression, the data were expressed as the mean \pm standard error of the mean. The data was tested with the Shapiro-Wilk normality test. Mixed-design ANOVA was used with $p<0.05$ that was considered statistically significant.

\section{RESULTS AND DISCUSSION}

\section{CARTILAGE-LIKE TISSUE MORPHOLOGY}

Cartilage TERM approach is perceived as a hope to solve cartilage damage or degeneration issue. A reproducible cartilaginous tissue implant formation is the ultimate goal for any cartilage TERM attempt. Hence, the evaluation of structural and functional aspects of the construct confirmed the construct's potential. In terms of the construct's macroscopic morphology, the in vitro and in vivo constructs had retained the disc-shaped structure and were reduced in their diameter as the time point increased (Figure 1). The in vivo constructs appeared to have a smoother, glossier surface and were more cartilage-like than the in vitro constructs. In addition, no significant difference has been noted between the PLGA/ fibrin and PLGA scaffold groups. Based on the resulted construct's morphology, it is possible that the secreted ECM has replaced the degraded biomaterial scaffold and are left with the formed tissue. Besides that, the scaffold size-reduction was perhaps affected by the in vivo microenvironment because of its ectopic implantation site. Although it was not implanted at the actual site, this cartilaginous tissue was able to grow under the skin. Hence, it is suggested that the chances of the construct to form cartilaginous tissue in the actual site of implantation may be high. 
a)
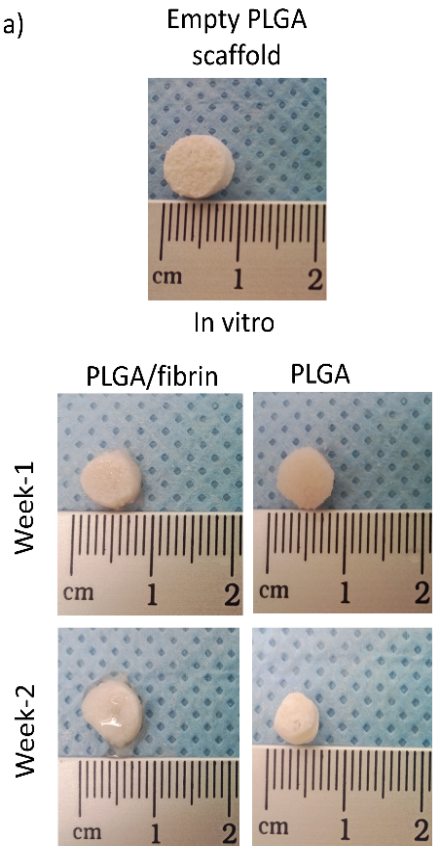

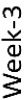

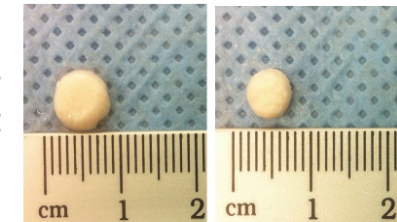

b)
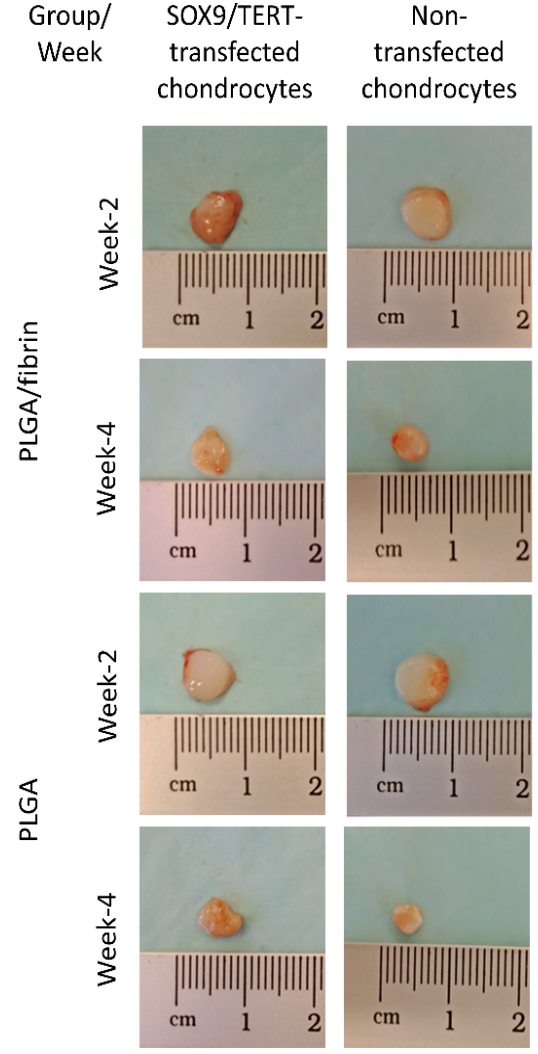

c)

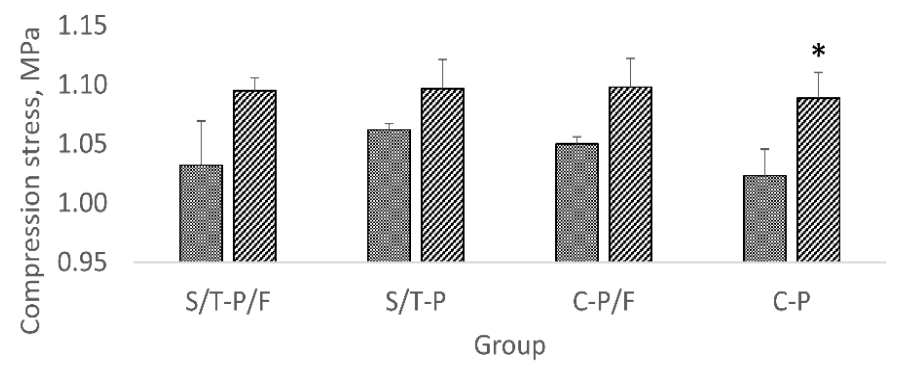

四 week 2 圆week 4

FIGURE 1. a) The representative images of in vitro construct gross morphology at week-1, week-2 and week-3, b) The representative images of in vivo construct at week-2 and week-4 \& c) The mechanical strength of the in vivo construct at week-2 and week-4. *represents $p<0.05$ that is considered as significant. The constructs abbreviation is listed in Table 1

\section{THE INCREMENT OF CONSTRUCT'S RIGIDITY INFLUENCED BY TISSUE'S HISTOARCHITECTURE}

A simple palpation test conducted on the in vivo construct indicated the increment of the construct's rigidity from week-2 to week-4 post-implantation (Figure 1(c)). The in vitro constructs were unable to retain its $3 \mathrm{D}$ structure and collapse upon palpation. The post-implanted construct's rigidity outcome was confirmed via compression-stress analysis. Regardless of scaffold groups, it was noted that the mechanical strength at week-4 of all in vivo construct was higher than the construct's strength at week-2. The mechanical strength of the construct groups had increased by 1.06-times, 1.04-times, 1.05-times, 1.07-times in SOX9/TERT-PLGA/fibrin, SOX9/TERT-PLGA, NTC-PLGA/fibrin, and NTC-PLGA, respectively. There were no significant differences between each week, 
$\mathrm{F}(1.00,5.00)=4.42, \mathrm{p}>0.05$. There was also no significant differences between each group, $\mathrm{F}(3.00,15.00)=0.91$, $\mathrm{p}>0.05$. There was no significant interaction between weeks and groups, $F(3.00,15.00)=0.42, p>0.05$.

Based on the result, it is noted that the construct's structure at week-2 is more porous than the construct at week-4 due to the lower mechanical strength value. It is believed that the cells interaction and ECM distribution contribute to the mechanical strength of the in vivo constructs (Wang et al. 2016). As supported by the histological visualisation (Figure 2(a)), less-homogenous cells and ECM infiltration had been observed in the construct at week-2, while the week-4 construct structure was wholly occupied with the matrix. From the visualisation, the resulted histoarchitecture of the week-4 construct was comparable with the one that was reported at week-16 post-implantation (Calabrese et al. 2017), indicating the cells dynamic interaction with the in vivo environment. While the in vitro cartilaginous tissue was formed thinly on the outer part of the scaffold corresponded to the unstable in vitro construct structure caused by the incomplete cells and matrix infiltration (Noorhidayah et al. 2019). In addition, there was no significant difference in terms of cartilage histoarchitecture formation in both PLGA/fibrin and PLGA scaffold groups.

\section{THE INCREASE OF CARTILAGINOUS MATRIX COMPONENT PRODUCTION IN THE IN VIVO CONSTRUCT}

The cartilaginous matrix components (sGAG and proteoglycan) secretion were in its infant state in the in vivo construct, even though the construct had exhibited cartilage histoarchitecture formation with distinct chondrocytes morphology in the matrix.

The blue stain of alcian blue representing positive sGAG indicator was visualised at the pericellular matrix region of the in vivo and in vitro constructs at all designated time points (Figure 2(b)). The sGAG was concentrated at the pericellular matrix region with less-homogenous distribution in the constructs. The distribution of sGAG in the matrix showed that the secretion of sGAG was still in its primitive stage in the in vivo construct, indicating that the formed cartilaginous tissue was young. In addition, the intense alcian blue stain in the week- 4 constructs was a sign that the formed cartilaginous tissue was progressing towards maturation. The histological outcome was supported by the quantitative sGAG content increment in the in vivo construct (Figure 2(c)). The sGAG content had increased by 1.40-times, 1.54-times, 2.55-times, 1.64-times in SOX9/TERT-PLGA/fibrin, SOX9/TERTPLGA, NTC-PLGA/fibrin and NTC-PLGA, respectively. There was no significant difference between each week, $\mathrm{F}(1.00,5.00)=1.77, \mathrm{p}>0.05$. There was also no significant difference between each group, $\mathrm{F}(3.00,15.00)=1.69$, $\mathrm{p}>0.05$. There was no significant interaction between weeks and groups, $F(3.00,15.00)=0.15, p>0.05$. There was an increment of quantitative sGAG content in the in vitro constructs (Noorhidayah et al. 2019). It showed that the sGAG had continuously been produced in both the in vitro and in vivo constructs as the time point increased.

The sGAG production stimulates the presence of proteoglycan in the matrix as it is made up of sGAG chains that are bonded with a core protein. In this study, proteoglycan visualisation through toluidine blue corresponds to the sGAG histological outcome. The dark purple stain of toluidine blue was detected at the pericellular matrix region in the in vivo and in vitro constructs (Figure 3(a)). As for the proteoglycan detection through safranin $\mathrm{O}$, an intense orange-red stain was displayed in the in vitro constructs indicating the presence of proteoglycan-rich matrix. In the in vivo constructs, the protein was more visible at the pericellular matrix region of week-4 in the SOX9/TERTPLGA/fibrin compared to the other groups (Figure 3(b)). The low detection of proteoglycan through safranin $\mathrm{O}$ is expected due to the stain having a low affinity towards sulphur in the tissue that can only be detected in mature cartilage (Schmitz et al. 2010). From the overall histology visualisation, it can be noted that the in vivo construct is a premature cartilaginous tissue.

Besides that, the presence of collagen type-II and collagen type-I were detected in the construct via immunohistochemistry staining (Figure 4). The immunopositivity of collagen type-II was noted in the in vitro and in vivo constructs with the accumulation of brown precipitation at the pericellular matrix region. Collagen type-II was expressed in all constructs at all designated time points. The collagen's immunoreaction was particularly homogenous in SOX9/TERT-PLGA/ fibrin compared to other constructs. As for the collagen type-I immunoreaction, the collagen was expressed in the in vitro setting. However, the brown precipitation was not visible at the pericellular matrix region in all in vivo constructs. Among all the constructs, SOX9/TERTPLGA/fibrin at week-4 had shown prominent negative collagen type-I immunoreaction.

Collagen type-II is a specific marker for hyaline cartilage and only presented in the mature cartilage. Despite that, the co-expression of collagen type-II and collagen type-I is known to be a sign of the developing cartilage (Munirah et al. 2008b; Noorhidayah et al. 2019), which is based on the previous rat tibial articular cartilage development study (Sasano et al. 1996). This event is noted in the 3D culture outcome which highlights the phenotypically immature in vitro cartilaginous tissue. Even so, the tissue is progressing towards maturation as the ectopic implanted construct has shown its potential as hyaline cartilage with the non-detected immunopositivity of collagen type-I in the groups. 
a) Native cartilage In vitro, week-3

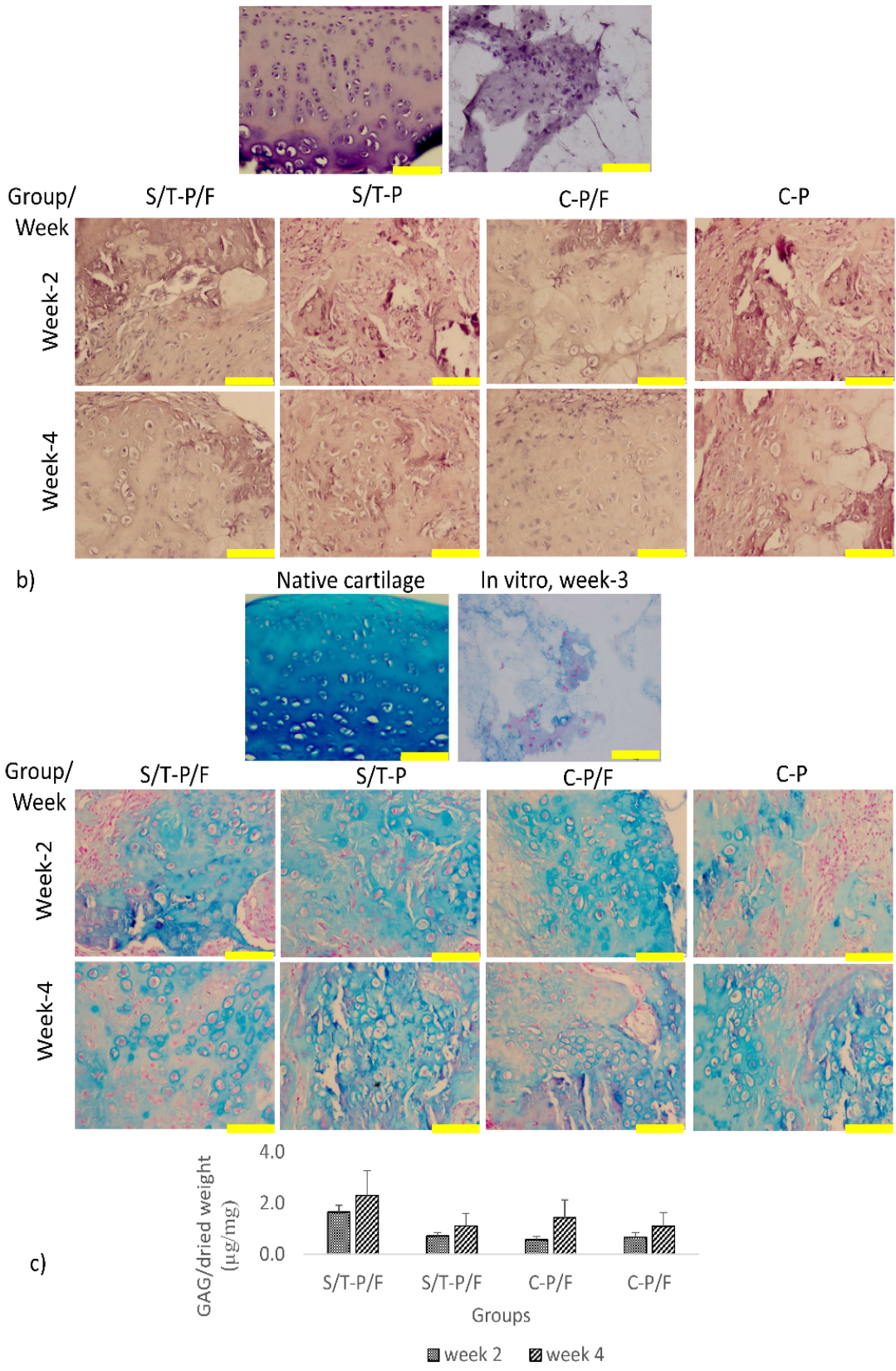

FIGURE 2. a) The images show the morphology or histoarchitecture of the in vivo construct that has been stained using haematoxylin and eosin, b) The presence of sGAG at the pericellular matrix region is indicated as the blue stain in the in vivo 'construct that has been stained using alcian blue'. Magnification $=200 X$. Scale bar $=100 \mu \mathrm{m}$ (yellow coloured) \& c) The quantitative sGAG content increment in the in vivo construct. *represents $p<0.05$ that is considered as significant. The constructs abbreviation is listed in Table 1 
a)
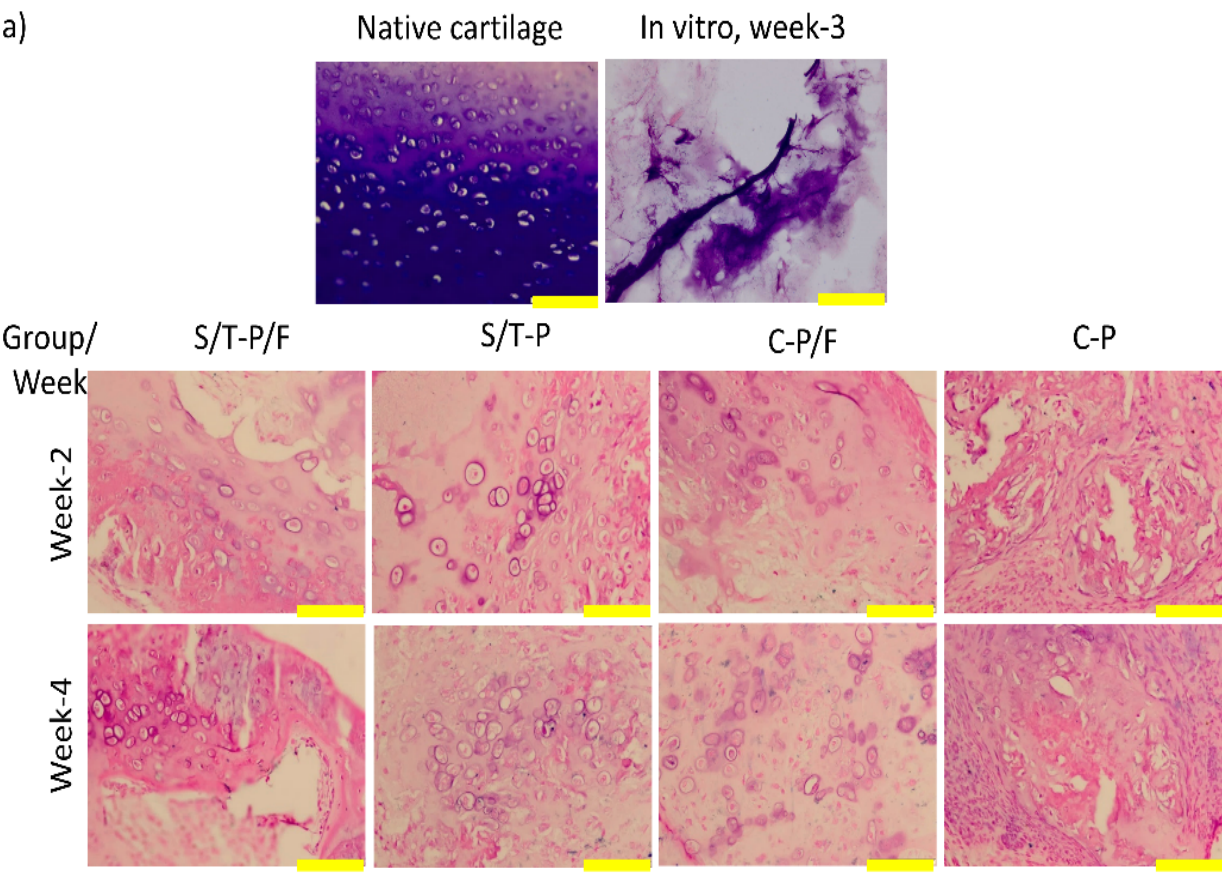

b)
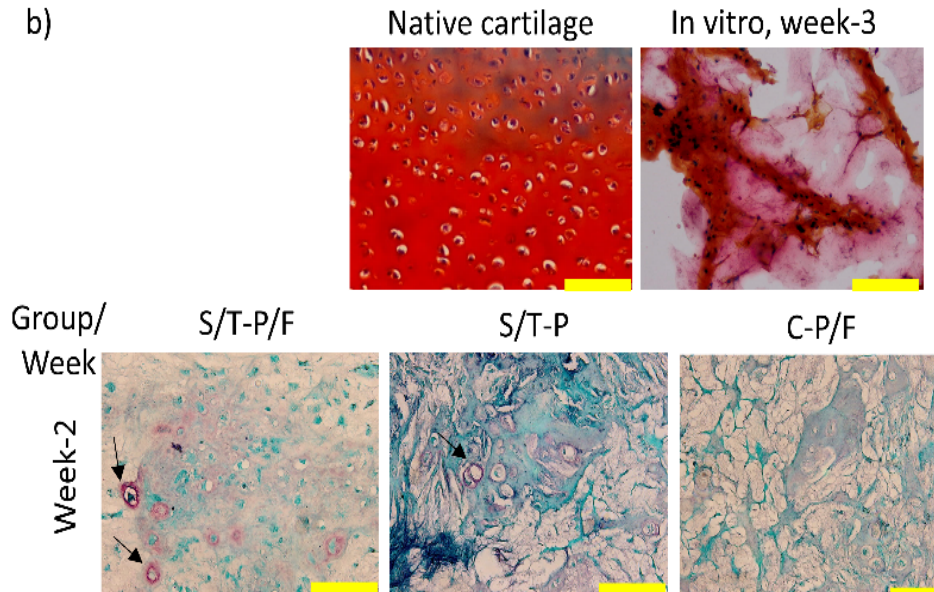

S/T-P

C-P/F

C-P
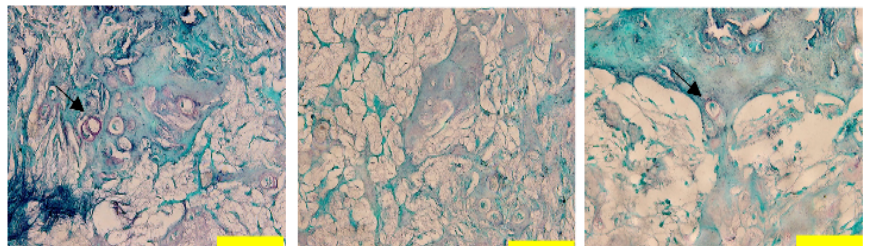

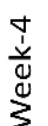
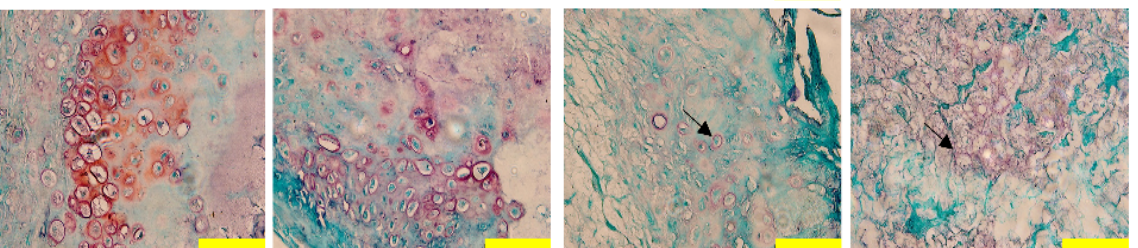

FIGURE 3. a) The presence of proteoglycan at the pericellular matrix region of the in vivo construct is indicated as the dark purple stain of toluidine blue $\& b$ ) The presence of proteoglycan at the pericellular matrix region of the in vivo construct is indicated as the orangered stain of safranin $\mathrm{O}$ has been detected, particularly in SOX9/TERT-PLGA/fibrin at week-4.

The arrows indicate the accumulation of proteoglycan at the pericellular matrix region. Magnification $=200 X$. Scale bar $=100 \mu \mathrm{m}$ (yellow coloured). The constructs abbreviation is listed in Table 1 
a)
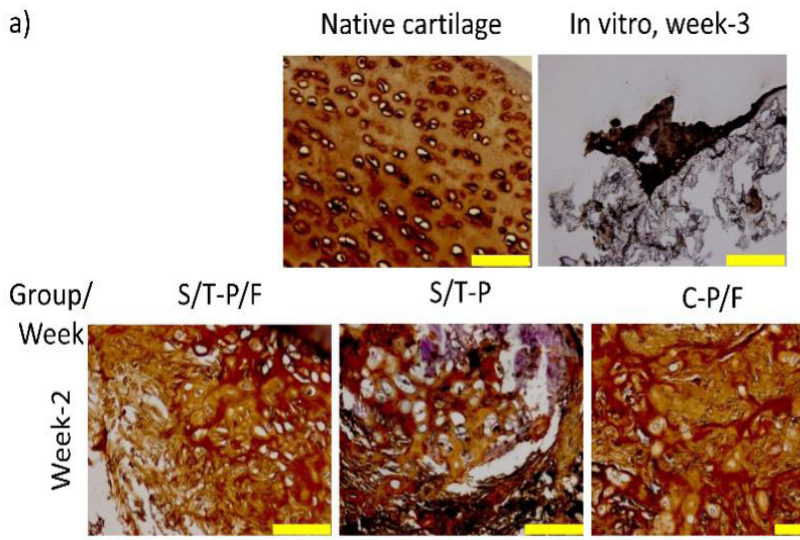

S/T-P

$C-P / F$

C-P
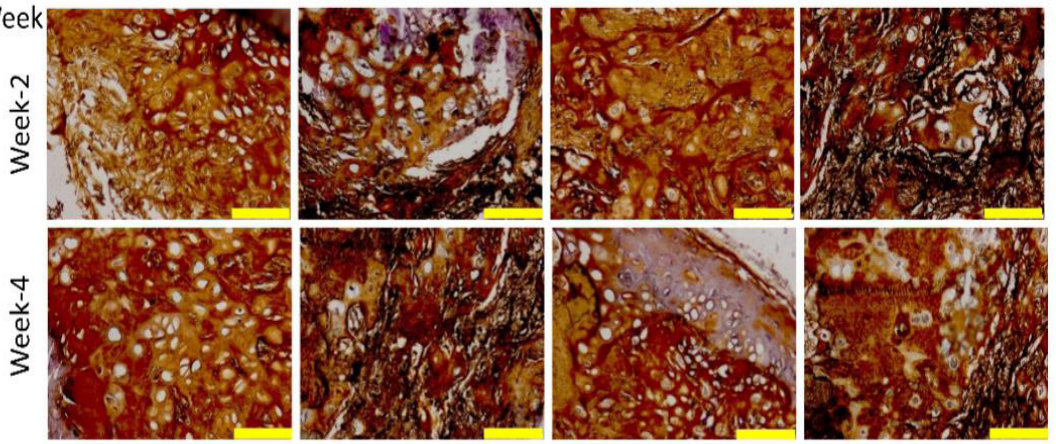

b)

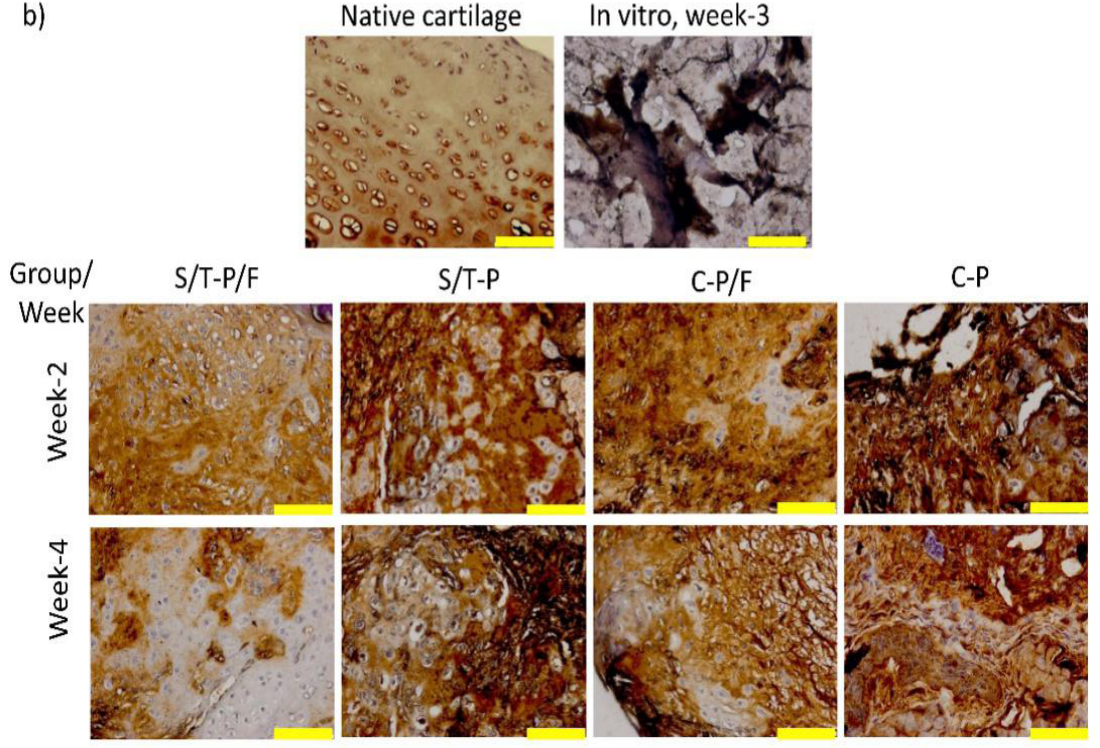

In vitro, week-3

FIGURE 4. a) The brown precipitation indicates the presence of collagen type-II at the pericellular matrix region of the in vivo construct using immunohistochemistry \& b) The brown precipitation indicates the presence of collagen type-I at the pericellular matrix region of the in vivo construct that has not been detected, particularly in SOX9/TERT-PLGA/fibrin at week-4. Magnification $=200 X$. Scale bar $=100 \mu \mathrm{m}$ (yellow coloured). The constructs abbreviation is listed in Table 1

THE UPREGULATION OF CARTILAGINOUS MARKERS EXPRESSION IN SOX9/TERT-PLGA/FIBRIN CONSTRUCT

The gene expression result demonstrated the upregulation of proteoglycan marker, ACAN in the in vivo SOX9/TERTPLGA/fibrin construct (Figure 5(a)). The gene expression was upregulated from $1.00 \pm 0.51$-fold at week- 2 to $3.63 \pm 0.58$-fold at week- 4 in the construct group, by 3.63-times. The $A C A N$ expression result indicates that there was no significant difference between each week, $\mathrm{F}(1.00,5.00)=0.58, \mathrm{p}>0.05$. There was also no significant difference between each group, $\mathrm{F}(3.00,15.00)=2.71$, $\mathrm{p}>0.05$. There was no significant interaction between weeks and groups, $\mathrm{F}(3.00,15.00)=2.71, \mathrm{p}>0.05$. The $A C A N$ expression level in SOX9/TERT-PLGA/fibrin corresponds to the histological visualisation, as the proteoglycan richmatrix was visibly increased in the construct through safranin $\mathrm{O}$ (the mature cartilage detector). In the in vitro constructs, the gene expression was also significantly upregulated in the SOX9/TERT-PLGA/fibrin (Noorhidayah et al. 2019). 
a)

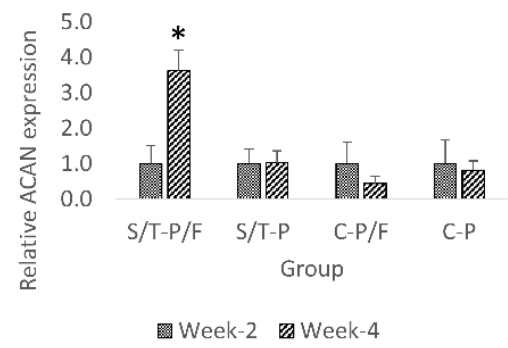

c)

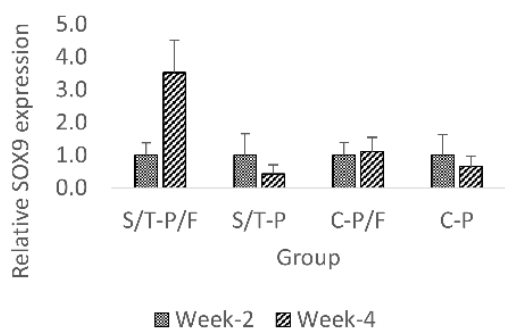

e)

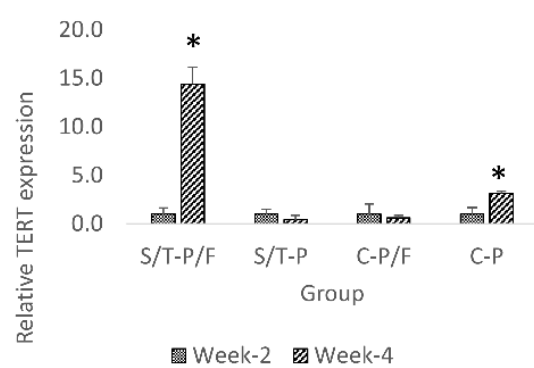

b)

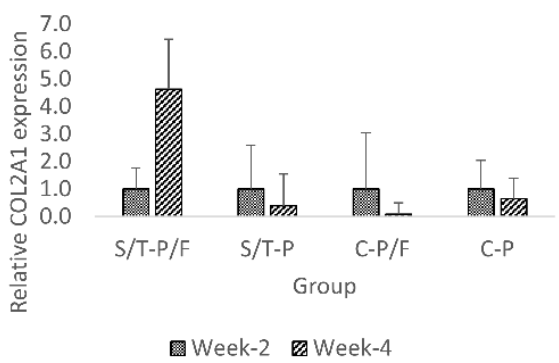

d)

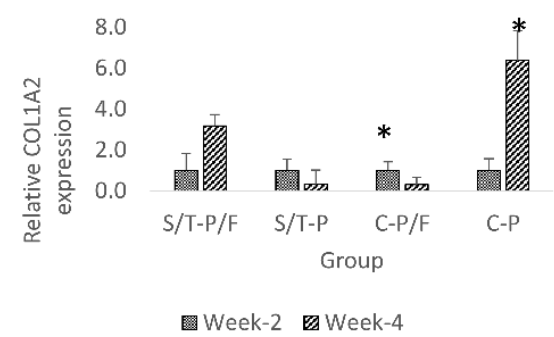

f)

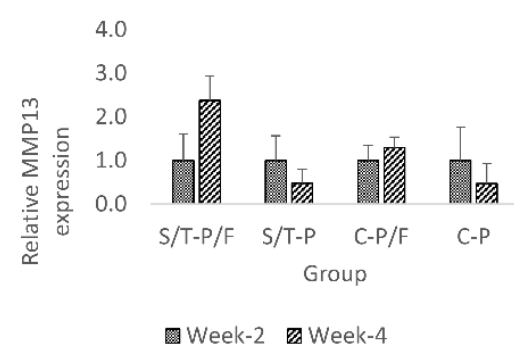

FIGURE 5. a) ACAN gene expression was upregulated in the in vivo SOX9/TERT-PLGA/ fibrin, b) COL2A1 gene expression was upregulated in the in vivo in SOX9/TERT-PLGA/ fibrin, c) $S O X 9$ gene expression was upregulated in the in vivo SOX9/TERT-PLGA/fibrin, d) COL1A2 gene expression was upregulated in the in vivo SOX9/TERT-PLGA/fibrin and NTC-PLGA, e) TERT gene expression was upregulated in the in vivo SOX9/TERT-PLGA/ fibrin and NTC-PLGA \& f) MMP13 gene expression was upregulated in the in vivo SOX9/ TERT-PLGA/fibrin and NTC-PLGA/fibrin. *represents $p<0.05$ that is considered as significant. The constructs abbreviation is listed in Table 1

Similar with $A C A N$ expression the in vivo construct, COL2A1 expression was upregulated in the SOX9/ TERT-PLGA/fibrin. The upregulation of COL2A1 gene expression was from $1.00 \pm 0.76$-fold at week2 to $4.63 \pm 1.81$-fold at week-4 (Figure 5(b)). There was no significant difference between each week, $\mathrm{F}(1.00,5.00)=2.48, \mathrm{p}>0.05$. There was also no significant difference between each group, $\mathrm{F}(1.11,5.53)=2.57$, $\mathrm{p}>0.05$. There was no significant interaction between weeks and groups, $F(1.11,5.53)=2.57, \mathrm{p}>0.05$. The gene was also upregulated in the in vitro constructs made of
SOX9/TERT-transfected chondrocytes, which were $S O X 9 /$ TERT-PLGA/fibrin and SOX9/TERT-PLGA (Noorhidayah et al. 2019).

The upregulation of $S O X 9$ gene in the in vivo $S O X 9 /$ TERT-PLGA/fibrin was expected as both $A C A N$ and COL2A1 were well-expressed in the construct (Figure 5(c)). SOX9 gene expression was increased by 3.52-times in the construct group. There was no significant difference between each week, $F(1.00,5.00)=0.01$, $\mathrm{p}>0.05$. There was a significant difference between each group, $\mathrm{F}(3.00,15.00)=4.21, \mathrm{p}<0.05$. Among the 
construct groups, there was a difference between $S O X 9 /$ TERT-PLGA and SOX9/TERT-PLGA/fibrin. There was also a significant interaction between weeks and groups, $\mathrm{F}(3.00,15.00)=4.21, \mathrm{p}<0.05$. In the in vitro setting, the gene's upregulation pattern was shared with the constructs that were formed using SOX9/TERT-transfected chondrocytes, SOX9/TERT-PLGA/fibrin, and SOX9/TERT-
PLGA (Figure 6(a)). There was a significant difference between each week, $F(1.06,5.31)=36.35, p<0.05$. Among the constructs, there was also a significant difference between each group, $F(7=1.60,8.01)=82.55, p<0.05$. There was a significant interaction between weeks and groups, $\mathrm{F}(1.94,9.71)=38.07, \mathrm{p}<0.05$.

a)
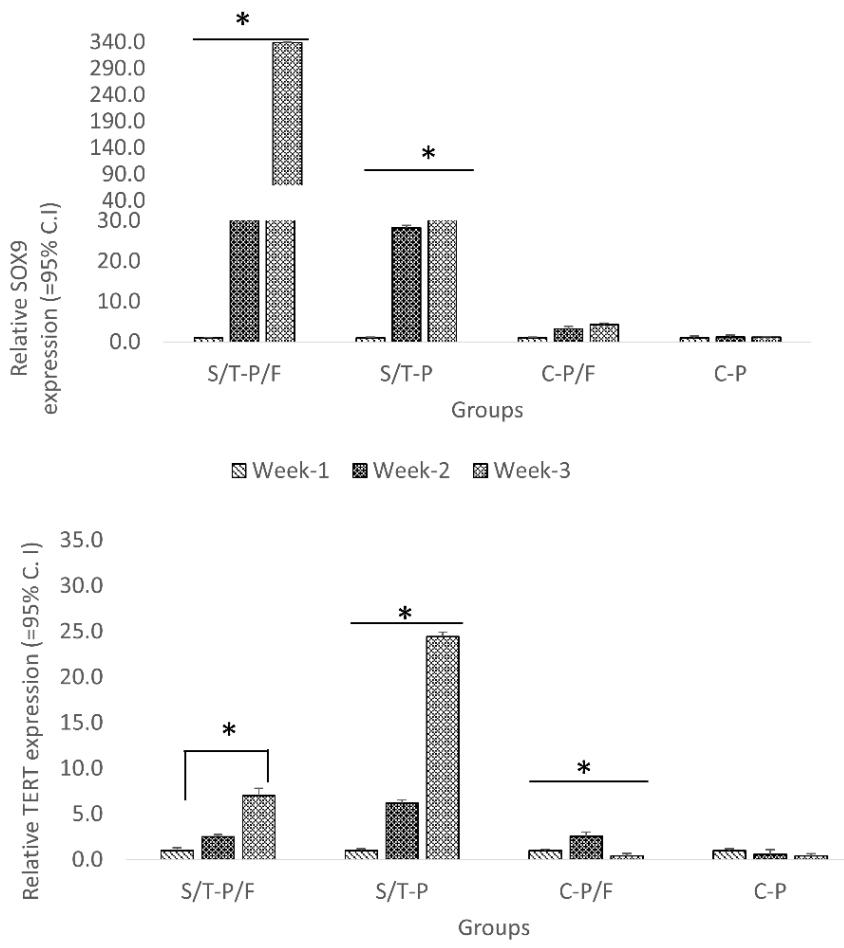

图Week-1 图Week-2 圈Week-3

c)

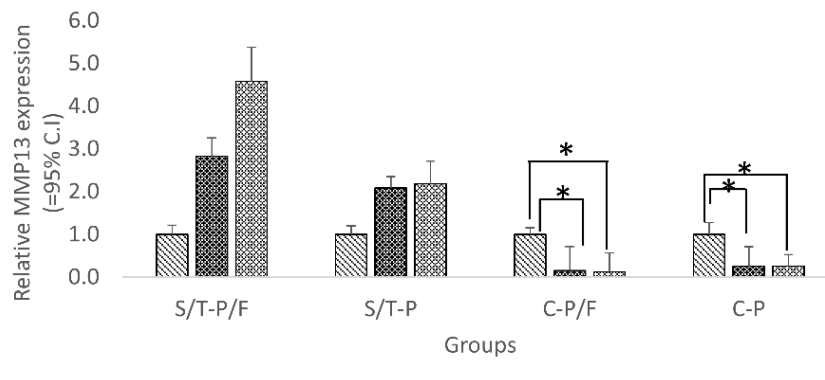

인 Week-1 图Week-2 圆Week-3

FIGURE 6. a) $S O X 9$ gene expression was upregulated in the in vitro $S O X 9 / T E R T$-PLGA/fibrin and SOX9/TERT-PLGA, b) TERT gene expression was upregulated in the in vitro SOX9/TERTPLGA/fibrin and SOX9/TERT-PLG \& c) MMP13 gene expression was upregulated in the in vitro SOX9/TERT-PLGA/fibrin and SOX9/TERT-PLGA. *represents $p<0.05$ that is considered as significant. The constructs abbreviation is listed in Table 1 
In the in vivo constructs, COL1A2 expression was upregulated in SOX9/TERT-PLGA/fibrin 3.17-times and 6.38-times in NTC-PLGA (Figure 5(d)), even though the constructs exhibited negative collagen type-I immunoreaction. There was no significant difference between each week, $F(1.00,5.00)=1.69, p>0.05$. There was a significant difference between each group, $\mathrm{F}(1.70,8.48)=5.73, \quad \mathrm{p}<0.05$. Among the construct groups, there was a difference between NTC-PLGA and NTC-PLGA/fibrin with SOX9/TERT-PLGA. There was also a significant interaction between weeks and groups, $\mathrm{F}(1.70,8.48)=5.73, \mathrm{p}<0.05$. While in the in vitro constructs, there were no changes in terms of COL1A2 expression in SOX9/TERT-PLGA/fibrin (Noorhidayah et al. 2019).

As for the TERT expression in the in vivo constructs, the gene was upregulated in SOX9/TERT-PLGA/fibrin by 14.40-times and NTC-PLGA by 3.21-times (Figure 5(e)). There was a significant difference between each week, $F(1.00,5.00)=9.18, p>0.05$. There was a significant difference between each group, $\mathrm{F}(3.00,15.00)=6.10$, $\mathrm{p}<0.05$. Among the construct groups, there was a difference between SOX9/TERT-PLGA/fibrin and NTCPLGA/fibrin with SOX9/TERT-PLGA. There was also a significant interaction between weeks and groups, $\mathrm{F}(3.00,15.00)=6.10, \mathrm{p}<0.05$. While in the in vitro setting, the gene was upregulated in SOX9/TERT-PLGA/ fibrin and SOX9/TERT-PLGA in the culture. There was no significant difference between each week, $\mathrm{F}(1.06,5.32)=5.59, \quad \mathrm{p}>0.05$. Among the construct groups, there was a significant difference between each group, $\mathrm{F}(2.90,14.52)=132.28, \mathrm{p}<0.05$. There was a significant interaction between weeks and groups, $\mathrm{F}(3.11,15.53)=52.28, \mathrm{p}<0.05$. The regulation of TERT in the constructs indicates that the cells have the potential in maintaining its lifespan longer than other constructs because the expressed gene is expected to decelerate the shortening of the telomere sequences during cell division and ultimately delay the apoptosis or senescence of the cells.

The expression of a cartilage-breakdown marker, $M M P 13$ is also being analysed in both in vitro and in vivo constructs. MMP13 targets collagen type-II, proteoglycan, collagen type-IV, collagen type-IX, osteonectin and perlecan which potentially induces arthritis, osteoarthritis and other tissue degrading diseases (Inada et al. 2004; Yamamoto et al. 2016). However, MMP13 is also involved in embryogenesis, morphogenesis, normal tissue remodelling and tissue repair (Inada et al. 2004; Yamamoto et al. 2016). In the in vitro setting, the gene expression was upregulated in SOX9/TERT-PLGA/fibrin, and SOX9/TERT-PLGA by 4.58-times and 2.18-times, respectively, from week-1 to week-3 (Figure 6(c)). There was a significant difference between each week, $\mathrm{F}(2.00,10.00)=114.47, \mathrm{p}<0.05$. Among the construct groups, there was also a significant difference between each group, $F(7.00,35.00)=61.72$, $\mathrm{p}<0.05$. There was a significant interaction between weeks and groups, $F(14.00,70.00)=53.95, p<0.05$. While in the in vivo construct, $M M P 13$ expression was upregulated in SOX9/TERT-PLGA/fibrin and NTC-PLGA/fibrin by 2.38-times and 1.29-times, respectively (Figure 5(f)). There was no significant difference between each week, $\mathrm{F}(1.00,5.00)=0.18, \mathrm{p}>0.05$. There was a significant difference between each group, $\mathrm{F}(3.00,15.00)=10.61$, $\mathrm{p}<0.05$. Among the construct groups, there was a difference between SOX9/TERT-PLGA/fibrin and NTC-PLGA with SOX9/TERT-PLGA. There was also a significant interaction between weeks and groups, $\mathrm{F}(3.00,15.00)=10.61, \mathrm{p}<0.05$. As supported by the coexpression of the collagens, MMP13 expression in the constructs was expected as it was also involved in the normal tissue repair and embryonic development. In the overall molecular expression analysis, it has been noted that the SOX9/TERT-PLGA/fibrin construct has superior phenotypic expression compared to the other construct groups.

In the previous finding, it has been noted that the synergy of SOXY and TERT genes facilitates the restoration of cells' phenotype in the $3 \mathrm{D}$ culture (Noorhidayah et al. 2019). As a continuation of the work, this study has demonstrated the cartilaginous potential of the implanted constructs that have been formed using SOX9/TERT-transfected chondrocytes, in particular the SOX9/TERT-PLGA/fibrin construct. The finding has also noted that the genes are able to maintain the cells' chondrogenic phenotype even with one time transfection reaction during monolayer culture (Noorhidayah et al. 2019).

The study has incorporated fibrin with PLGA as it has been proven to soften the inflammatory response, facilitate cell adhesion and proliferation better than PLGA only scaffold (Rozlin et al. 2015). Fibrin seems to accommodate chondrocytes adaptation in the culture medium that may have been affected by the acidic PLGA by-product (Lih et al. 2018). Besides, our previous report has shown that the PLGA/fibrin scaffold promotes better cartilage histoarchitecture than PLGA scaffold in vitro (Noorhidayah et al. 2019).

Based on the histology visualisation, it is noted that the in vivo environment facilitates tissue growth in stages, where cell proliferation takes place leading to tissue maturation which is confirmed by the concentrated sGAG and proteoglycan at the pericellular matrix region. Nonetheless, a longer implantation period is required to observe tissue maturation (structurally and functionally) or any possible biological effects to the host. It is also suggested to conduct an actual site implantation (orthotopic) assessment on the construct as the tested biological condition is more accurate, and the outcome may differ from ectopic implantation in terms of cells migration and cells' phenotype expression. Further investigation on the SOX9/TERT-PLGA/fibrin construct is encouraged because it has the potential to be commercialised as the tissue-engineered product that will contribute to the advancement of organ loss treatment modality. 


\section{CONCLUSION}

This study demonstrated the cartilage-like tissue formation in the in vivo environment. It is noted that the SOX9/TERT-PLGA/fibrin construct has exhibited superior phenotypic cartilaginous expression compared to the other construct groups. Through histology, the finding suggested that the cells in the construct had successfully secreted the cartilaginous matrix components. However, the formed tissue is still in its infancy and undergoing a maturation process. The histoarchitecture difference of the constructs in both experimental settings indicates that the in vivo setting provides a dynamic environment for complete tissue growth compared to the in vitro $3 \mathrm{D}$ culture. The extended assessment through orthotopic implantation is necessary in order to obtain in-depth information and understanding of the implanted tissue.

\section{ACKNOWLEDGEMENTS}

The authors thanked the Kulliyyah of Allied Health Sciences (KAHS), IIUM and Ministry of Science, Technology and Innovation (MOSTI) for providing ScienceFund (SF14-012-0062). The authors also thanked the research team members, KAHS, Dr. Tong Chuan He from University of Chicago, USA for pCDNA3-SOX9 and Dr. Bob Weinberg from Massachusetts Institute of Technology, USA for pBABE-neo-hTERT.

\section{REFERENCES}

Alsberg, E., Anderson, K.W., Albeiruti, A., Rowley, J.A. \& Mooney, D.J. 2002. Engineering growing tissues. Proceedings of the National Academy of Sciences 99(19): 12025-12030.

Calabrese, G., Gulino, R., Giuffrida, R., Forte, S., Figallo, E., Fabbi, C., Salvatorelli, L., Memeo, L., Gulisano, M. \& Parenti, R. 2017. In vivo evaluation of biocompatibility and chondrogenic potential of a cell-free collagen-based scaffold. Frontiers in Physiology 8: 984.

Choi Jiye \& Yong Jeong 2017. Elevated emotional contagion in a mouse model of Alzheimer's Disease is associated with increased synchronization in the insula and amygdala. Scientific Reports 7: 1-9.

Deng, Y.H., Lei, G.H., Lin, Z.X., Yang, Y.H., Lin, H. \& Tuan, R.S. 2019. Engineering hyaline cartilage from mesenchymal stem cells with low hypertrophy potential via modulation of culture conditions and Wnt/ $\beta$-catenin pathway. Biomaterials 192: 569-578.

Elakkiya Venugopal, Narmadha Rajeswaran, K. Santosh Sahanand, Amitava Bhattacharyya \& Selvakumar Rajendran. 2019. In vitro evaluation of phytochemical loaded electrospun gelatin nanofibers for application in bone and cartilage tissue engineering. Biomedical Materials 14(1): 015004.

Inada, M., Wang, Y.M., Byrne, M.H., Rahman, M.U., Miyaura, C., Lopez-Otin, C. \& Krane, S.M. 2004. Critical roles for collagenase-3 (Mmp13) in development of growth plate cartilage and in endochondral ossification. Proceedings of the National Academy of Sciences 101(49): 17192-17197.

Karlsson, M. \& Björnsson, S. 2001. Quantitation of proteoglycans in biological fluids using Alcian Blue. In Methods in
Molecular Biology, edited by Lozzo, R.V. Totowa, NJ: Prote. Humana Press Inc.

Kavand, H., Van Lintel, H. \& Renaud, P. 2019. Efficacy of pulsed electromagnetic fields and electromagnetic fields tuned to the ion cyclotron resonance frequency of $\mathrm{Ca} 2+$ on chondrogenic differentiation. Journal of Tissue Engineering and Regenerative Medicine 13(5): 799-811.

Kudva, A.K., Luyten, F.P. \& Patterson, J. 2018. In vitro screening of molecularly engineered polyethylene glycol hydrogels for cartilage tissue engineering using periosteum-derived and ATDC5 cells. International Journal of Molecular Sciences 19(11): 3341.

Joydip Kundu, Shim, J.H., Jang, J.N., Kim, S.W. \& Cho, D.W. 2013. An additive manufacturing-based PCL-Alginatechondrocyte bioprinted scaffold for cartilage tissue engineering. Journal of Tissue Engineering and Regenerative Medicine 9(11): 1286-1297.

Lih, E., Kum, C.H., Park, W.R., Chun, S.Y., Cho, Y.J., Joung, Y.K. \& Park, K.S. 2018. Modified magnesium hydroxide nanoparticles inhibit the inflammatory response to biodegradable poly(lactide- co-glycolide) implants. ACS Nano. 12(7): 6917-6925.

Liu, Y., Tian, K., Hao, J., Yang, T., Geng, X.L. \& Zhang, W.G. 2019. Biomimetic poly (glycerol sebacate)/polycaprolactone blend scaffolds for cartilage tissue engineering. Journal of Materials Science: Materials in Medicine 30(5): 53.

Mohd Yunus Mohd Heikal, Shuid Ahmad Nazrun, Kien Hui Chua \& Abd Ghafar Norzana. 2019. Stichopus chloronotus aqueous extract as a chondroprotective agent for human chondrocytes isolated from osteoarthitis articular cartilage in vitro. Cytotechnology 71(2): 521-537.

Munirah Sha'ban, Ruszymah, Hj Idrus, Samsudin Osman Cassim, Badrul, A.H.M.Y., Azmi Baharudin \& Aminuddin Saim. 2008a. Autologous versus pooled human serum for articular chondrocyte growth. Journal of Orthopaedic Surgery 16(2): 220-229.

Munirah Sha'ban, Soon Hee Kim., Ruszymah Hj Idrus \& Gilson Khang. 2008b. The use of fibrin and poly(lactic-co-glycolic acid) hybrid scaffold for articular cartilage tissue engineering: An in vivo analysis. European Cells and Materials 15: 41-52.

Noorhidayah Md Nazir, Ahmad Hafiz Zulkifly, Kamarul Ariffin Khalid, Ismail Zainol, Zaitunnatakhin Zamli \& Munirah Sha>ban. 2019. Matrix production in chondrocytes transfected with sex determining region Y-Box 9 and telomerase reverse transcriptase genes: An in vitro evaluation from monolayer culture to three-dimensional culture. Tissue Engineering and Regenerative Medicine 16(3): 285-299.

Ogura, T., Bryant, T., Merkely, G. \& Minas, T. 2019. Autologous chondrocyte implantation for bipolar chondral lesions in the patellofemoral compartment: Clinical outcomes at a mean 9 years' follow-up. American Journal of Sports Medicine 47(4): 837-846.

Prosser, A., Scotchford, C., Roberts, G., Grant, D. \& Sottile, V. 2019. Integrated multi-assay culture model for stem cell chondrogenic differentiation. International Journal of Molecular Sciences 20(4): 951.

Rozlin Abdul Rahman, Norhamiza Mohamad Sukri, Noorhidayah Md Nazir, Muhammad Aa'zamuddin Ahmad Radzi, Ahmad Hafiz Zulkifly, Aminudin Che Ahmad, Abdurezak Abdulahi Hashi, Suzanah Abdul Rahman \& Munirah Sha'ban. 2015. The potential of 3-dimensional construct engineered from 
poly(lactic-co-glycolic acid)/fibrin hybrid scaffold seeded with bone marrow mesenchymal stem cells for in vitro cartilage tissue engineering. Tissue and Cell 47(4): 420-430.

Sabatino, M.A., Santoro, R., Gueven, S., Jaquiery, C., Wendt, D.J., Martin, I., Moretti, M. \& Barbero, A. 2012. Cartilage graft engineering by co-culturing primary human articular chondrocytes with human bone marrow stromal cells. Pediatric Endocrinology Reviews 9(12): 1394-1403.

Sasano, Y., Furusawa, M., Ohtani, H., Mizoguchi, I., Takahashi, I. \& Kagayama, M. 1996. Chondrocytes synthesize type I collagen and accumulate the protein in the matrix during development of rat tibial articular cartilage. Anatomy and Embryology 194(3): 247-252.

Schmitz, N., Laverty, S., Kraus, V.B. \& Aigner, T. 2010. Basic methods in histopathology of joint tissues. Osteoarthritis and Cartilage 18: 113-116.

Vermeulen, S., Vasilevich, A., Tsiapalis, D., Roumans, N., Vroemen, P., Beijer, N.R.M., Dede-Eren, A., Zeugolis, D. \& de Boer, J. 2019. Identification of topographical architectures supporting the phenotype of rat tenocytes. Acta Biomaterialia 83: 277-290.

Wang, T.Y., Lai, J.H., Han, L-H., Tong, X.M. \& Yang, F. 2016. Modulating stem cell-Chondrocyte interactions for cartilage repair using combinatorial extracellular matrix-containing hydrogels. Journal of Materials Chemistry B 4(47): 76417650.

Yamamoto, K., Okano, H., Miyagawa, W., Visse, R., Shitomi, Y., Santamaria, S., Dudhia, J., Troeberg, L., Strickland, D.K., Hirohata, S. \& Nagase, H. 2016. MMP-13 is constitutively produced in human chondrocytes and co-endocytosed with ADAMTS-5 and TIMP-3 by the endocytic receptor LRP1. Matrix Biology 56: 57-73.

Zhang, X.D., Qi, L., Chen, Y.H., Xiong, Z.Z., Li, J.J., Xu, P., Pan, Z.Q., Zhang, H.Z., Chen, Z.X., Xue, K. \& Liu, K. 2019. The in vivo chondrogenesis of cartilage stem/progenitor cells from auricular cartilage and the perichondrium. American Journal of Translational Research 11(5): 2855-2865.

Zhang, X.W., Wu, S.L., Naccarato, T., Prakash-Damani, M., Chou, Y., Chu, C-Q. \& Zhu, Y. 2017. Regeneration of hyaline-like cartilage in situ with SOX9 stimulation of bone marrow-derived mesenchymal stem cells. PLoS ONE 12(6): e0180138.
Zhu, Y.Q., Zhang, Y.Y., Yu, L., Tao, R., Xia, H.T., Zheng, R., Shi, Y., Tang, S.J., W.J., Zhang., Liu, W., Cao, Y.L. \& Zhou, G.D. 2014. Influence of Chm-I knockout on ectopic cartilage regeneration and homeostasis maintenance. Tissue Engineering Part A 21(3-4): 782-792.

Noorhidayah Md Nazir \& Zaitunnatakhin Zamli Department of Biomedical Science

Kulliyyah of Allied Health Sciences International Islamic University Malaysia (IIUM) Jalan Sultan Ahmad Shah, Bandar Indera Mahkota 25200 Kuantan, Pahang Darul Makmur Malaysia

Ahmad Hafiz Zulkifly \& Kamarul Ariffin Khalid Department of Orthopaedics

Traumatology and Rehabilitation

Kulliyyah of Medicine International Islamic University Malaysia (IIUM) Jalan Hospital Campus 25100 Kuantan, Pahang Darul Makmur Malaysia

Ismail Zainol

Department of Chemistry

Faculty of Science and Mathematics

Universiti Pendidikan Sultan Idris (UPSI)

35900 Tanjong Malim, Perak Darul Ridzuan

Malaysia

\section{Munirah Sha'ban*}

Department of Physical Rehabilitation Sciences Kulliyyah of Allied Health Sciences International Islamic University Malaysia (IIUM) Jalan Sultan Ahmad Shah, Bandar Indera Mahkota 25200 Kuantan, Pahang Darul Makmur Malaysia

*Corresponding author; email: munirahshaban@iium.edu.my

Received: 29 July 2019

Accepted: 29 January 2020 